\title{
The Implementation of Cipp Model in Evaluation MGMP Indonesian Language Program at Senior High School 11, Bekasi
}

\author{
Eka Septiani*), \\ Universitas Negeri Jakarta \\ Muchlas Suseno, \\ Universitas Negeri Jakarta \\ Samsi Setiadi, \\ Universitas Negeri Jakarta \\ *) Correspondences author: J1. Rambutan No. 29, Bekasi, 17431, Indonesia; \\ e-mail: ekaseptiani_9906921029@mhs.unj.ac.id
}

\begin{abstract}
Program evaluation is a form of mechanism used to review program processes that have been implemented over a certain period of time. The review is intended to understand, explore, and correct deficiencies in the program itself. This study was evaluation research using the CIPP model (Context, Input, Process, Product) developed by Stufflebeam. The evaluation subjects were organizer of MGMP, instructors and principal in SMAN 11, Bekasi. The evaluation was conduted in SMAN 11, Bekasi. The data obtained are presented in descriptive qualitative form. Interview, observation, and documentation were utilized as instruments to collect the data. The results of this evaluation reveal that the dimensions of MGMP program planning are generally quite good in terms of the specified context aspect criteria. The dimensions of human resource capacity in implementating the MGMP program have not been optimal in running the program based on the specified input aspect criteria. The dimension of the implementation of the MGMP program have not met all the elements of the process aspect criteria. The dimension of achievement of the MGMP program in improving professionalism of Indonesian language teachers at SMAN 11, Bekasi have been achieved based on the success indicators that have been determined in product aspect.
\end{abstract}

Keywords: MGMP, Program Evaluation, CIPP.

Article History: Received: 24/11/2021; Revised: 14/12/2021; Accepted: 16/12/2021; Published: 30/12/2021

How to Cite (MLA 7th): Septiani, Eka, Muchlas Suseno, and Samsi Setiadi. "The Implementation of Cipp Model in Evaluation MGMP Indonesian Language Program at Senior High School 11, Bekasi." Hortatori Jurnal Pendidikan Bahasa dan Sastra Indonesia 5.2 (2021): 107-117. Print/Online. Copyrights Holder: Eka Septiani, Muchlas Suseno, Samsi Setiadi. First Publication: Hortatori Jurnal Pendidikan Bahasa dan Sastra Indonesia (2017).

\section{Pendahuluan}

Guru merupakan elemen terpenting dalam pendidikan. Guru menjadi salah satu faktor penentu tinggi rendahnya mutu hasil pendidikan. Salah satu yang diharapkan agar dapat membantu peningkatan kualitas mutu seorang guru adalah sebuah wadah yang dinamakan Musyawarah Guru Mata Pelajaran (MGMP). Istilah ini dipakai sekumpulan guru setingkat SMP dan SMA/ SMK sebagai sarana untuk meningkatkan profesionalitas bagi guru semua mata pelajaran baik secara individu maupun organisasi (Juwairiyah, 2014: 2). Upaya peningkatan mutu pembelajaran yang dilakukan melalui MGMP yang diarahkan untuk meningkatkan mutu pembelajaran yang bermuara pada peningkatan hasil belajar siswa, meliputi peningkatan pengetahuan dan keterampilan guru baik dalam pemahaman dan pengembangan materi, pemilihan metode dan strategi pembelajaran, penggunaan/pembuatan media dan alat peraga sederhana, pelaksanaan penilaian, pemberian bimbingan, pengelolaan kelas, pengembangan sikap 
108 The Implementation of Cipp Model in Evaluation MGMP Indonesian Language Program at Senior High School 11 , Bekasi

profesionalisme, dan penerapan inovasi dan perkembangan baru dalam dunia pendidikan. Salah satu fungsi MGMP adalah sebagai wadah untuk memecahkan permasalaan yang terdapat pada guru yang menjadi anggota di dalamnya (Yanti et al., 2018). Kehadiran MGMP tidak boleh dipandang sebelah mata walau terkadang pelaksanaannya masih kurang maksimal. Program MGMP Bahasa Indonesia menjadi sebuah program rutin yang diadakan oleh SMA 11 BEKASI untuk mendukung proses pembelajaran bahasa Indonesia yang tentunya didukung dengan adanya faktor pendukung lainnya seperti bahan ajar, fasilitas, atau sarana prasarana. Dengan bahan ajar, fasilitas, atau sarana prasarana yang memadai, apabila proses pelaksanaan pembelajarannya baik dan berkualitas, maka akan berdampak positif terhadap kualitas produk yang dihasilkan, yaitu input yang diproses secara baik diharapkan akan menjadi produk berkualitas (Oktaviyani, A., Herpratiwi, dan Sukirlan, 2015).

Diperlukan sebuah penilaian untuk dapat menilai keberhasilan dari sebuah program yang dilaksanakan. Penilaian merupakan bagian yang tidak terpisahkan dari proses pembelajaran. Penilaian dapat dilakukan melalui evaluasi. (Mesiono, 2020) mengatakan evaluasi merupakan bagian integral dalam dimensi input, proses dan output pendidikan. Evaluasi dilakukan dalam rangka pengendalian mutu pendidikan kepada pihak-pihak yang berkepentingan, di antaranya terhadap peserta didik, lembaga, dan program pendidikan (Sukardi, 2012). Sebuah program perlu dilakukan evaluasi. Evaluasi program disimpulkan oleh (Munthe, 2015) sebagai suatu proses pencarian informasi, penemuan informasi dan penetapan informasi yang dipaparkan secara sistematis tentang perencanaan, nilai, tujuan, manfaat, efektivitas, dan kesesuaian sesuatu dengan kriteria dan tujuan yang telah ditetapkan. Evaluasi program inilah yang akan menilai berhasil atau tidaknya program MGMP Bahasa Indonesia yang dilaksanakan di SMAN 11 BEKASI. Terdapat beberapa model evaluasi yang bisa digunakan oleh seorang guru dalam menilai keberhasilan sebuah program. Model evaluasi yang bisa digunakan untuk mengevaluasi program MGMP adalah model CIPP (Contexs, Input, Prosess, Product). CIPP memiliki kemampuan untuk menyelidiki ke dalam empat aspek yang berbeda tetapi saling terkait dari sebuah program (Osokayo, dkk, dalam Junanto and Nur, 2018). Keempat evaluasi model CIPP dapat digambarkan melalui gambar 1.

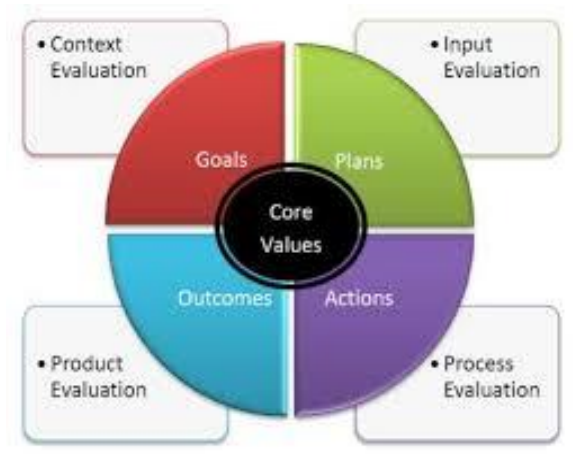

Gambar 1. Komponen Evaluasi Model CIPP

Sumber: (Mawarsari et al., 2014)

CIPP merupakan sebuah model evaluasi yang pertama kali diperkenalkan oleh Stufflebeam. Sebagaimana yang dikatakan oleh (Asfaroh et al.). Context, Input, Process, and Product (CIPP) is the first evaluation model used for education and was introduced by Stufflebeam in 1965. CIPP is systematically designed as the guide to evaluate the learning process, starting from the beginning of the assessment (context and input evaluation), during the implementation (input and process evaluation), to the final evaluation of the learning outcomes (product evaluation) (Zhang G, Zeller N, Griffith R, Metcalf D, Williams J, Shea C). Diperlukan beberapa komponen dalam mengevaluasi. Berikut ini komponenkomponen yang akan dievaluasi menggunakan model CIPP.

Konteks (Context) merupakan komponen pertama yang ada pada model CIPP. Konteks dalam sebuah evaluasi bertujuan mengkaji tujuan yang ada. Sebagaimana dijelaskan oleh (Mahmudi, 2011) Evaluasi konteks juga bertujuan untuk menilai apakah tujuan-tujuan dan prioritas-prioritas yang telah ditetapkan memenuhi kebutuhan-kebutuhan pihak-pihak yang menjadi sasaran organisasi. Evaluasi pada bagian konteks berfokus pada evaluasi kegiatan yang berkaitan dengan analisis kebutuhan sebuah program. 
Selain menentukan kebutuhan program, dalam konteks ini evaluasi juga dapat menjadi tujuan program yang ditentukan.

Evaluasi masukan (Input) adalah kerangka dari keputusan. Evaluasi menurut (Ortiz et al., 2015) Tiene como objetivo central ayudar a diseñar un programa para efectuar los cambios necesarios. Evaluasi masukan bertujuan untuk membantu mengatur suatu keputusan, menentukan sumber, alternatif yang akan diambil, apa rencana dan strategi untuk mencapai kebutuhan, dan bagaimana prosedur kerja untuk mencapainya. Evaluasi masukan berkaitan erat dengan penentuan sumber dan strategi apa saja yang akan digunakan untuk mencapai tujuan dari sistem atau program yang dievaluasi. Contoh sumber yang mempengaruhi upaya untuk mencapai tujuan tersebut adalah bagaimana sarana dan prasarana di lingkungan belajar, komponen tenaga pendidik, dan penggunaan media pembelajaran. Berdasarkan uraian di atas, dapat diketahui bahwa evaluasi masukan terkait dengan strategi apa yang dapat digunakan untuk mencapai kebutuhan yang belum atau tidak dapat dicapai. Evaluasi input dapat juga digunakan untuk mencari hambatan dan potensi sumber daya yang tersedia.

Proses evaluasi (Process )sangat erat kaitannya dengan pembelajaran dan evaluasi proses difokuskan pada seberapa efektif pengaruh dari penerapan sistem atau program yang dievaluasi. Evaluasi yang dirancang dan diaplikasikan dalam praktik implementasi kegiatan disebut dengan evaluasi proses. Untuk melihat apakah pelaksanaan program sudah sesuai dengan strategi yang telah dilaksanakan tersebut, maka perlu diadakannya evaluasi. Evaluasi tersebut dinamakan evaluasi proses. Evaluasi proses menurut (Mufid, 2020) berguna dalam mengetahui kekuatan dan kelemahan dari program yang mungkin tidak diketahui sebelumnya. Data yang dihasilkan di sini dapat digunakan untuk memperbaiki program sebelum terlambat. Evaluasi proses termasuk mengidentifikasi permasalahan prosedur pada pelaksanaan kejadian dan aktivitas. Setiap perubahan-perubahan yang terjadi pada aktivitas dimonitor secara jujur dan cermat. Pencatatan aktivitas harian penting dilakukan karena berguna pada pengambilan keputusan untuk menentukan tindak lanjut penyempurnaan dan menentukan kekuatan dan kelemahan program.

Evaluasi Hasil (Product) adalah evaluasi yang bertujuan untuk mengukur, menginterpretasikan, dan menilai pencapaian program. Hal ini senada dengan pendapat (Fahruddin, 2020) Evaluasi produk merupakan penilaian yang dilakukan untuk mengukur keberhasilan dalam pencapaian tujuan yang telah ditetapkan. Evaluasi terhadap hasil atau produk bertujuan untuk mengetahui hasil apa yang telah dicapai dari implementasi sistem atau program, dan tindak lanjut apa yang akan dilakukan setelah sistem atau program tertentu dilaksanakan. Informasi yang diperoleh dari evaluasi produk ini sangat penting karena evaluasi hasil akan menentukan tindak lanjut yang akan diambil. Di dalam komponen ini, harus ada hasil yang telah dicapai dari suatu program dan apa yang harus dilakukan setelah program berjalan. Evaluasi bertujuan untuk membantu pengambilan keputusan selanjutnya. Evaluasi produk berkaitan dengan analisis terhadap hasil implementasi sistem atau program. Informasi yang diperoleh dapat menunjukkan hasil dari apa yang telah dicapai sehingga informasi dapat ditentukan oleh langkah selanjutnya yang dilakukan untuk menindaklanjuti sistem atau program di masa yang akan datang.

(Bulhayat, 2019) menjelaskan penilaian konteks ditujukan untuk menginformasikan keputusan perencanaan, Evaluasi Input adalah untuk melayani keputusan struktural, sedangkan Evaluasi Proses adalah untuk memandu keputusan implementasi, dan Penilaian Produk untuk melayani pengambilan keputusan ulang. Keempat unsur dalam model evaluasi CIPP secara lebih lengkap dijelaskan dalam tabel berikut:

Tabel 1. Model Evaluasi CIPP

\begin{tabular}{|c|c|c|c|c|}
\hline & Evaluasi Konteks & Evaluasi Input & Evaluasi Proses & Evaluasi Produk \\
\hline Tujuan & $\begin{array}{c}\text { Menentukan konteks } \\
\text { organisasi, } \\
\text { mengidentifikasi sasaran } \\
\text { program \& menilai } \\
\text { kebutuhankebutuhan } \\
\text { mereka, mengidentifikasi } \\
\text { peluang untuk memenuhi } \\
\text { kebutuhan mereka, } \\
\text { mendiagnosis masalah- } \\
\text { masalah yang melatari } \\
\text { kebutuhan itu,dan menilai } \\
\text { apakah tujuan yang sudah } \\
\text { ditetapkan cukup } \\
\text { responsif terhadap } \\
\text { kebutuhankebutuhan yang } \\
\text { telah dinilai itu. }\end{array}$ & $\begin{array}{c}\text { Mengidentifikas i \& } \\
\text { menilai kemampuan } \\
\text { sistem, alternatif strategi } \\
\text { program, desain prosedur } \\
\text { untuk menerapkan } \\
\text { strategi, budget, \& jadwal } \\
\text { program }\end{array}$ & $\begin{array}{c}\text { Mengidentifikasi atau } \\
\text { memprediksi, selama } \\
\text { proses berlangsung, } \\
\text { kesalahankesalahan } \\
\text { desain prosedur atau } \\
\text { pelaksanaannya; } \\
\text { memberikan informasi } \\
\text { untuk mengambil } \\
\text { keputusan yang belum } \\
\text { diprogramkan; dan } \\
\text { mencatat dan menilai } \\
\text { peristiwaperistiwa dan } \\
\text { aktivitas-aktivitas } \\
\text { prosedural. }\end{array}$ & $\begin{array}{c}\text { Mengumpulkan } \\
\text { deskripsi dan penilaian } \\
\text { tentang hasil-hasil } \\
\text { program; mengaitkan } \\
\text { mereka dengan tujuan, } \\
\text { konteks, input, dan } \\
\text { proses; dan menafsirkan } \\
\text { keberhargaan dan } \\
\text { manfaat program. }\end{array}$ \\
\hline
\end{tabular}


110 The Implementation of Cipp Model in Evaluation MGMP Indonesian Language Program at Senior High School 11 , Bekasi

$$
\begin{array}{c|c}
\text { Metode } & \begin{array}{c}
\text { Analisis sistem, survai, } \\
\text { analisis dokumen, } \\
\text { hearing, wawancara, tes } \\
\text { diagnostik, dan teknik } \\
\text { Delphi. }
\end{array}
\end{array}
$$

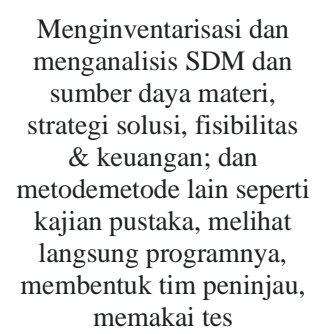

Untuk memilih sumber pendukung, strategi solusi $\&$ desain prosedur, misalnya untuk melakukan perubahanperubahan secara tertata; dan memberikan dasar untuk menilai pelaksanaan program.

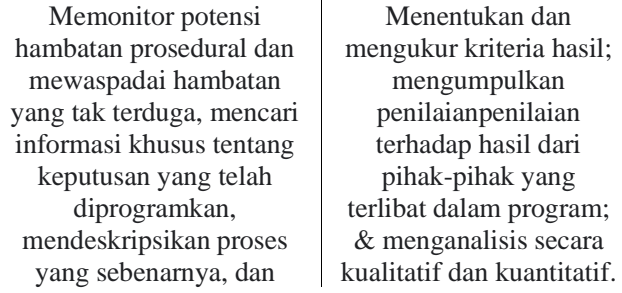

Memonitor potensi

hambatan prosedural dan mewaspadai hambatan yang tak terduga, mencari informasi khusus tentang keputusan yang telah diprogramkan, mendeskripsikan proses yang sebenarnya, dan

Menentukan dan

mengukur kriteria hasil; mengumpulkan penilaianpenilaian terhadap hasil dari pihak-pihak yang terlibat dalam program; \& menganalisis secara kualitatif dan kuantitatif. berinteraksi dengan staf dan mengamati aktivitas mereka

Untuk melaksanakan dan menyempurnaka $\mathrm{n}$ desain dan prosedur program, misalnya untuk

mengawasi proses; \& memberikan catatan tentang proses yang sebenarnya untuk menafsirkan hasil-hasil program.

$$
\begin{gathered}
\text { Untuk memutuskan } \\
\text { apakah akan } \\
\text { melanjutkan, } \\
\text { menghentikan, } \\
\text { memodifikasi program, } \\
\text { atau memfokuskan } \\
\text { ulang pada perubahan; } \\
\text { \& memberikan catatan } \\
\text { yang jelas tentang } \\
\text { dampaknya (yang sesuai } \\
\text { dengan maksud \& } \\
\text { tujuan awal atau tidak, } \\
\text { yang positif atau } \\
\text { negatif). }
\end{gathered}
$$

Sumber: (Mahmudi, 2011)

Penelitian terkait evaluasi program menggunakan model CIPP memang sudah banyak. Akan tetapi penelitian terkait evaluasi program pembelajaran bahasa di tingkat SMA menggunakan model CIPP masih jarang ditemukan. Model evaluasi ini dapat digunakan untuk mengetahui sejauh mana peserta didik telah menguasai tujuan khusus pembelajaran yang ingin dicapai oleh sebab itu seorang guru hendaknya secara terus menerus mengikuti hasil belajar yang telah dicapai oleh peserta didiknya. Informasi yang diperoleh dari evaluasi model CIPP ini merupakan umpan balik terhadap pembelajaran bahasa Indonesia yang telah dilaksanakan di SMAN 11 BEKASI dan output apa yang didapatkan. Evaluasi model CIPP dalam proses pembelajaran ini sangat dibutuhkan ini merupakan upaya untuk memperoleh informasi tentang perolehan belajar siswa secara menyeluruh baik pengetahuan, sikap, maupun keterampilan. Dari uraian permasalahan tersebut akan dinilai sebagai berikut: 1. Bagaimana penerapan program MGMP dengan menggunakan evaluasi model CIPP (Contexs, Input, Prosess, Product)? 2. Bagaimana pelaksanaan MGMP yang telah berjalan dalam pembelajaran bahasa Indonesia? 3. Bagaimana hasil evaluasi program MGMP dengan menggunakan evaluasi model CIPP (Contexs, Input, Prosess, Product)?

\section{Metode}

Diperlukan sebuah metode untuk melakukan evaluasi program yang sudah berjalan. Metode penelitian yang digunakan untuk mengevaluasi program MGMP adalah metode deskriptif. Penelitian Deskriptif digunakan untuk menggambarkan atau menganalisis suatu hasil penelitian tetapi tidak digunakan untuk membuat kesimpulan yang lebih luas, sedangkan pendekatan yang digunakan dalam mengevaluasi program ini adalah kualitatif. Pendekatan kualitatif digunakan untuk menganalisis sebuah teori dengan memeriksa hubungan antarvariabel. Teknik pengumpulan data yang digunakan di antara adalah teknik Observasi, Wawancara, dan Dokumentasi. Metode observasi dilakukan dengan menggunakan instrumen, yang berupa lembar pengamatan langsung ke lapangan dalam pelaksanan evaluasi program menggunakan metode CIPP. Sebelum dilakukan wawancara terhadap subjek penelitian, peneliti menyiapkan kerangka pertanyaan dalam pelaksanan evaluasi program menggunakan metode CIPP. Metode wawancara digunakan untuk memperjelas hasil observasi sehingga permasalahan dapat terlihat secara mendalam dan detail. Metode dokumentasi digunakan untuk mencari data mengenai hal-hal atau variabel yang berupa catatan, buku, surat kabar, majalah, agenda, dan sebagainya.

Setelah metode pengumpulan data dilakukan tahap selanjutnya adalah tahapan monitoring dan evaluasi menggunakan model Context-Input-Process-Product (CIPP). Evaluasi Program MGMP dengan menggunakan model CIPP ini digunakan untuk penilaian konteks yang meliputi perencaan program $M G M P$. Informasi yang dikumpulkan digunakan sebagai dasar dalam pertimbangan program. Penilaian 
input meliputi SDM dalam program MGMP. Data dikumpulkan selama tahap penilaian digunakan sebagai pengambil keputusan. Penilaian proses adalah kegiatan penilaian selama pelaksanaan program MGMP. Penilaian ini berkaitan langsung pengelolaan program MGMP. Penilaian produk/output, berhubungan dengan hasil pelaksanaan program. Penilaian dilakukan untuk mengetahui sampai seberapa jauh program MGMP ini telah berhasil mencapai tujuan berdasarkan kriteria yang ditetapkan.

\section{Hasil dan Diskusi}

Hasil dari penelitian ini adalah mengetahui penerapan program MGMP yang dapat dilihat dari dimensi Aspek Evaluasi Indikator Kriteria Perencanaan Program MGMP Context (Konteks) Merencanakan program. - Ada visi dan misi. - Ada tujuan. - Rencana kerja. - Program kerja (umum, inti, dan penunjang). - Stuktur organisasi. - Legalitas pengurus. - Keanggotaan. - Narasumber. - Sumber dana. - Sarana prasarana. Evaluasi Input (Masukan) Mengevaluasi SDM MGMP. - Pengurus. - Anggota - Narasumber sesuai pedoman MGMP. Pelaksanaan Program MGMP Process (Proses) Keterlaksanaan program. - Pengelolaan program. - Pengelolaan dana. - Keterlaksanaan program umum. - Keterlaksanaan program inti. Pencapaian Program MGMP Product (Hasil) Pencapaian tujuan program. - Peningkatan kinerja. - Peningkatan kompetensi. - Peningkatan profesionalisme. berikut.

Hasil evaluasi Context (Konteks) Program MGMP Bahasa Indonesia SMAN 11 BEKASI sebagai

\section{Visi dan misi MGMP Bahasa Indonesia SMAN 11 BEKASI}

Visi MGMP yaitu Terbentuknya guru Bahasa Indonesia SMA Negeri 11 Bekasi yang profesional berdasarkan nilai-nilai religius, inovatif, berbudi luhur, dan peduli lingkungan. Kemudian dijabarkan ke dalam misi yang terdiri atas lima poin, yaitu: Bekerja sama untuk mengembangkan akhlak terpuji melalui transfer nilai moral dan keteladanan kepada peserta didik; Mengikuti kegiatan-kegiatan untuk menunjang perkembangan dan meningkatkan profesionalisme guru Bahasa Indonesia SMA Negeri 11 Bekasi; Aktif mengikuti kerja sama dengan organisasi MGMP Bahasa Indonesia Kota Bekasi untuk meningkatkan mutu guru Bahasa Indonesia SMA Negeri 11 Bekasi; Mengadakan pertemuan MGMP Bahasa Indonesia SMA Negeri 11 Bekasi untuk mendiskusikan dan menindaklanjuti aspirasi anggota MGMP yang bermanfaat untuk perkembangan dan meningkatkan profesionalisme guru Bahasa Indonesia SMA Negeri 11 Bekasi; Menyediakan kanal youtube media pembelajaran Bahasa Indonesia dengan nama MGMP Bahasa Indonesia SMAN 11 Bekasi, demi meningkatkan kompetensi peserta didik. Perumusan visi dan misi merupakan salah satu bagian dari perencanaan Program MGMP yang terdapat dalam Standar Pengelolaan.

\section{Tujuan}

Tujuan MGMP Bahasa Indonesia SMA Negeri 11 Bekasi adalah: a) Menumbuhkan kegairahan guru mata pelajaran Bahasa Indonesia untuk meningkatkan kemampuan dan keterampilan dalam mempersiapkan, melaksanakan dan mengevaluasi program kegiatan belajar mengajar di sekolah. b) Mendiskusikan permasalahan yang dihadapi oleh guru Bahasa Indonesia dalam melaksanakan kegiatan belajar mengajar. c) Membantu guru memperoleh informasi teknis edukatif kerkaitan dengan implementasi kurikulum, baik yang berkaitan dengan materi, metodologi, maupun sistem evaluasi. d) Meningkatkan rasa kebersamaan dan tanggung jawab guru mata pelajaran Bahasa Indonesia serta saling berbagai informasi dan pengalaman dalam rangka memperkaya wawasan.

\section{Program MGMP}

Program yang disusun menyentuh apa yang dibutuhkan oleh guru dan berdasarkan analisis kebutuhan, seperti: penyusunan buku kerja, pembuatan kisi-kisi soal, dan materi-materi lain yang dibutuhkan oleh anggota. Penyusunan program mengacu pada jenis program yang dirancang, yaitu: program umum dan program inti. Program yang disusun dituangkan ke dalam program kerja MGMP satu tahun. Kemudian, disosialisasikan anggota pada pertemuan kegiatan MGMP. Dapat dikatakan bahwa program MGMP Bahasa Indonesia telah sesuai dengan Standar Program yang ditetapkan oleh Ditjen PMPTK. Pengelolaan program Aspek pelaksanaan program mengacu pada: 1. Pedoman kerja MGMP yang mengatur berbagai aspek pengelolaan secara tertulis yang mudah dibaca oleh pihak-pihak yang terkait. 2 . Struktur organisasi MGMP berisi tentang: (a) sistem penyelenggaraan dan administrasi yang diuraikan secara jelas dan transparan; (b) semua pimpinan dan anggota mempunyai uraian tugas, wewenang, dan 
112 The Implementation of Cipp Model in Evaluation MGMP Indonesian Language Program at Senior High School 11 , Bekasi

tanggung jawab yang jelas tentang keseluruhan penyelenggaraan dan administrasi MGMP. 3. Kegiatan MGMP dilaksanakan dengan: (a) berdasarkan rencana kerja tahunan dan disesuaikan dengan kebutuhan; (b) memperhitungkan sumber pendanaan yang dimiliki MGMP. Selanjutnya, pengelolaan kegiatan MGMP menjadi tanggung jawab pengurus MGMP. Para anggota melaksanakan kegiatan dengan berpedoman pada program kerja yang disusun oleh pengurus. Akan tetapi, berdasarkan hasil evaluasi, pengelolaan Program MGMP belum memenuhi salah satu unsur pada Standar Pengelolaan karena belum memiliki pedoman kerja. Pada Standar Pemantauan belum melakukan evaluasi terhadap kegiatan yang telah dilaksanakan sesuai Standar Pemantauan.

\section{Rencana Kerja}

Rencana kerja merupakan suatu kegiatan yang terkoordinasi untuk mencapai tujuan tertentu dalam kurun waktu tertentu. Para anggota melaksanakan kegiatan dengan berpedoman pada program kerja yang disusun oleh pengurus. Rencana kerja tersebut disusun untuk dilaksanakan selama satu tahun. Selama satu tahun kedepan, MGMP Bahasa Indonesia akan melaksanakan program-program kegiatan yang berhubungan dengan peningkatan profesi guru Bahasa Indonesia dalam kegiatan belajar mengajarnya. Kegiatan MGMP Bahasa Indonesia terdapat dalam tabel 2 di bawah ini.

Tabel 2. Kegiatan MGMP Bahasa Indonesia SMAN 11 Bekasi Selama Satu Tahun

\begin{tabular}{ll}
\hline \multicolumn{1}{c}{ BULAN } & \multicolumn{1}{c}{ KEGIATAN } \\
\hline Juni 2021 & Workshop Menyusun buku kerja \\
Juli 2021 & Merancang materi, media, dan metode pembelajaran \\
Agustus 2021 & Menyusun kisi-kisi dan soal Penilaian Harian bahasa Indonesia kelas X \\
September 2021 & Menyusun kisi-kisi dan soal Penilaian Harian bahasa Indonesia kelas XI \\
Oktober 2021 & Menyusun kisi-kisi dan soal Penilaian Harian bahasa Indonesia kelas XII \\
November 2021 & Evaluasi materi yang telah diberikan dan menganalisis nilai siswa \\
Desember 2021 & Menyusun kisi-kisi dan soal Penilaian Semester Ganjil bahasa Indonesia kelas X, XI, dan XII \\
Januari 2022 & Merancang materi, media, dan metode pembelajaran \\
Februari 2022 & Menyusun kisi-kisi dan soal Penilaian Harian 1 bahasa Indonesia kelas X, XI, XII, dan menyusun soal Try out \\
& kelas XII tingkat sekolah. \\
Maret 2022 & Menyusun kisi-kisi dan soal Penilaian Harian 2 bahasa Indonesia kelas X, XI, XII, dan menyusun soal Try out \\
& kelas XII tingkat sekolah. \\
April 2022 & Menyusun kisi-kisi dan soal Penilaian Harian 3 bahasa Indonesia kelas X, XI, XII, dan menyusun soal Try out \\
Mei 2022 & kelas XII tingkat sekolah. \\
\end{tabular}

Evaluasi konteks bertujuan untuk menilai apakah tujuan-tujuan dan prioritas-prioritas yang telah ditetapkan memenuhi kebutuhan-kebutuhan pihak-pihak yang menjadi sasaran organisasi. Hasil evaluasi konteks pada program MGMP sudah memenuhi kebutuhan pihak yang menjadi sasaran organisasi dengan terpenuhinya visi, misi, tujuan, program dan rencana kerja. Semua kriteria ini sudah terpenuhi.

Evaluasi masukan berkaitan erat dengan penentuan sumber dan strategi apa saja yang akan digunakan untuk mencapai tujuan dari sistem atau program yang dievaluasi serta sarana dan prasarana yang ada dalam program MGMP. Hasil evaluasi Input (Masukan) Program MGMP Bahasa Indonesia SMAN 11 BEKASI sebagai berikut.

\section{Kepengurusan.}

Hasil wawancara dengan ketua MGMP periode 2020--2022 diperoleh data bahwa pengurus telah melaksanakan tugas dan tanggung jawabnya dengan baik, meletakkan dasar-dasar yang kuat bagi MGMP agar MGMP dapat terus berjalan. Pengurus mengemas kegiatan MGMP dengan cara diisi dengan arisan guru Bahasa Indonesia setiap bulan agar anggota aktif dalam pertemuan. Pengurus periode 2020--2022 berusaha melaksanakan tugas dan tanggung jawabnya. Pelaksanaan Program MGMP tentu tidak terlepas dari kendala, seperti masalah dana. Akan tetapi, para pengurus berusaha mengatasi kendala yang ada agar kegiatan dapat tetap terlaksana sesuai jadwal. Tugas pengurus dalam pelaksanaan kegiatan adalah berkoordinasi dengan narasumber untuk memberikan materi dalam setiap kegiatan MGMP. Seluruh kegiatan yang telah dilaksanakan selama satu tahun menjadi tugas dari pengurus untuk membuat laporannya. Pengurus melaporkan pelaksanaan Program MGMP dan mempertanggungjawabkannya pada rapat pengurus serta anggota dalam bentuk laporan pada akhir tahun yang disampaikan sebelum penyusunan rencana kerja berikutnya. Laporan yang telah dipertanggungjawabkan, disampaikan ke Kepala Sekolah. 
MGMP Bahasa Indonesia pada Standar Pengelolaan sudah mempunyai uraian tugas untuk masingmasing pengurus. Hasil wawancara dan observasi terhadap dokumen diperoleh data bahwa struktur kepengurusan MGMP tahun 2021-2022 di antaranya:

Ketua : Irvan Hartarto, M.Pd.

Sekretaris : Irma Yusfita, S.Pd.

Anggota $\quad:$ : Sisworohati, M.Pd.

2. Dra. Nani Setianingsih

3. Reza Dwi Saputra, S.Pd.

\section{Narasumber}

Penetapan narasumber dalam kegiatan dilakukan pada saat merancang/menyusun program kerja yang akan dilaksanakan selama satu tahun. Narasumber dalam kegiatan MGMP Bahasa Indonesia telah sesuai dengan kriteria yang ditentukan dalam Standar SDM. Narasumber dalam kegiatan MGMP Bahasa Indonesia, yaitu:

a. Instruktur Guru Penggerak dari Direktorat

b. Wakasek Bidang Kurikulum SMAN 11 BEKASI, Ibu Hj. Ririn Setyorini, M, Pd.

c. Ketua MGMP, Bapak Irvan Hartarto, M.Pd.

\section{Sumber Dana}

Dana untuk menunjang penyelenggaraan kegiatan MGMP Bahasa Indonesia berasal dari dana Bantuan Operasional Sekolah (BOS). Adapun penggunaan dana ditujukan untuk membiayai program rutin. sumber dana untuk menunjang kegiatan MGMP Bahasa Indonesia telah sesuai dengan ketentuan dalam Standar Pembiayaan. Pengelolaan dana Dana yang masuk dan penggunaannya dilaporkan secara transparan pada saat pertemuan yang dilaksanakan. Laporan penggunaan dana dilaporkan secara administratif kepada anggota pada saat rapat akhir tahun. Biaya investasi dan operasional MGMP disosialisasikan kepada seluruh anggota untuk menjamin tercapainya pengelolaan dana secara transparan. Berdasarkan hal itu maka, pengelolaan dana MGMP Bahasa Indonesia telah sesuai dengan Standar Pembiayaan yang ditentukan.

\section{Sarana Prasarana}

Tempat penyelenggaraan kegiatan MGMP Bahasa Indonesia dilaksanakan di SMAN 11 Bekasi. Alamat Komp. Perwira Tinggi, Kav. Pati TNI AU, Jl. . Alamat email: mail.sman11bekasi@gmail.co. Sarana prasarana tambahan seperti laboratorium bahasa, perpustakaan, dan internet sebagai pendukung penyelenggaraan kegiatan MGMP. Perencanaan Program MGMP Bahasa Indonesia SMAN 11 BEKASI meliputi visi dan misi, tujuan, program kerja, struktur kepengurusan, keanggotaan, narasumber, sumber dana, serta sarana prasarana MGMP telah sesuai dengan kriteria aspek context evaluation (evaluasi konteks) yang ditetapkan.

Hasil evaluasi Process (Proses) Program MGMP Bahasa Indonesia SMAN 11 BEKASI dapat dilihat dari bagaimana pelaksanaan program MGPM. Pelaksanaan program umum dalam kegiatan MGMP, yaitu pemberian materi tentang regulasi dan kebijakan di bidang pendidikan, misalnya kurikulum. Selain itu, pemberian materi terkait inovasi-inovasi pembelajaran. Keterlaksanaan program umum MGMP telah sesuai dengan teori dan Standar Program MGMP yang ditetapkan.

Keterlaksanaan program inti Program inti meliputi: membahas permasalahan pembelajaran di kelas; penyusunan RPP; model-model pembelajaran; metode-metode pembelajaran; media pembelajaran; pemahaman dan pendalaman materi pembelajaran atau teks; pembahasan materi dan soal-soal Ujian Nasional; penilaian pembelajaran; silabus; bedah SKL; materi pembelajaran; diseminasi kompetensi sosial dan kompetensi kepribadian. Keterlaksanaan program inti telah sesuai dengan kriteria yang ditetapkan oleh Ditjen PMPTK. Berdasarkan deskripsi di atas, maka disimpulkan bahwa pelaksanaan program MGMP belum memenuhi semua unsur yang ditetapkan pada aspek evaluasi proses (process evaluation).

Adapun beberapa kegiatan Program MGMP Bahasa Indonesia yang sudah berjalan di SMAN 11 BEKASI, di antaranya:

a. Kegiatan MGMP berbasis digital yang diadakan selama dua hari, 27—30 Juli 2020. 
114 The Implementation of Cipp Model in Evaluation MGMP Indonesian Language Program at Senior High School 11 , Bekasi
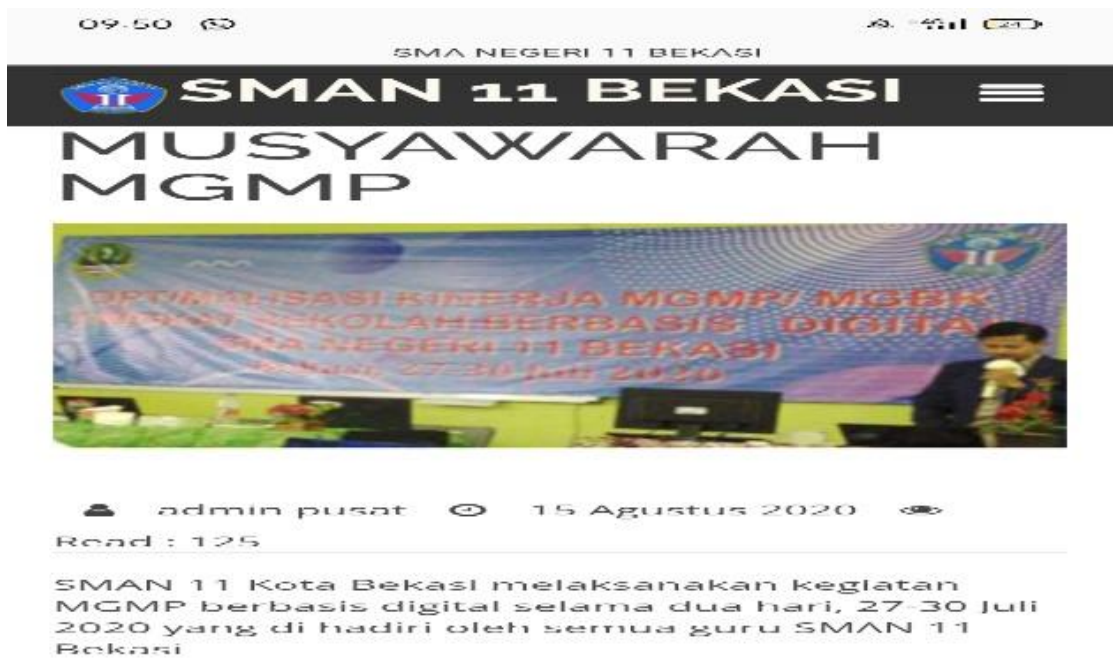

Pank?

Gambar 2. Kegiatan MGMP Berbasis Digital

b. Optimalisasi MGMP Sekolah Berkelanjutan "Aplikasi E-Belajar dalam Pembelajaran" yang dilaksanakan pada 16 November 2020.

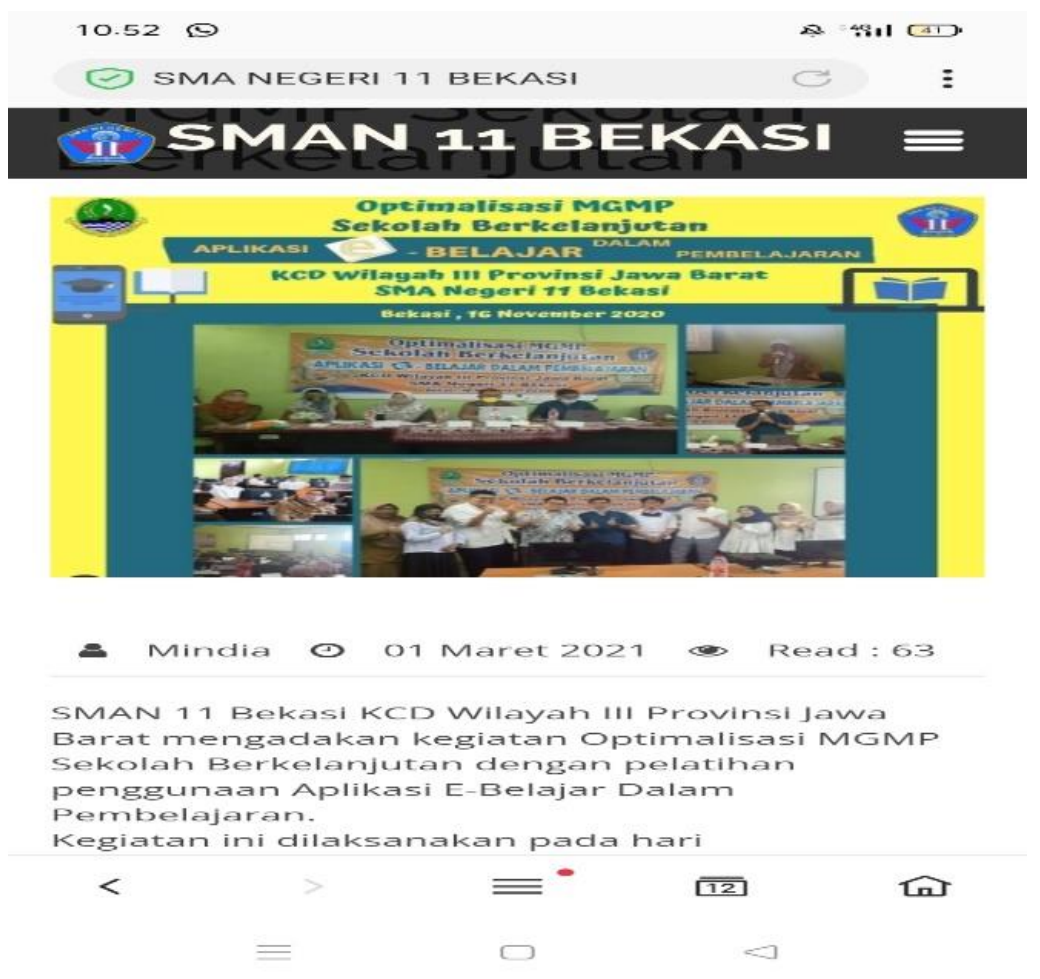

Gambar 3. Optimalisasi MGMP Berkelanjutan “Aplikasi E-Belajar dalam Pembelajaran”

c. Pembinaan MGMP Berkelanjutan "Pembuatan Video Pembelajaran Milenial yang dilaksanakan pada tanggal 15-16 Januari 2021. 
$10.53 @$

$\Delta$ se.

\section{SMAN I1 BEKASI}

Berkelanjutan

(2) i )

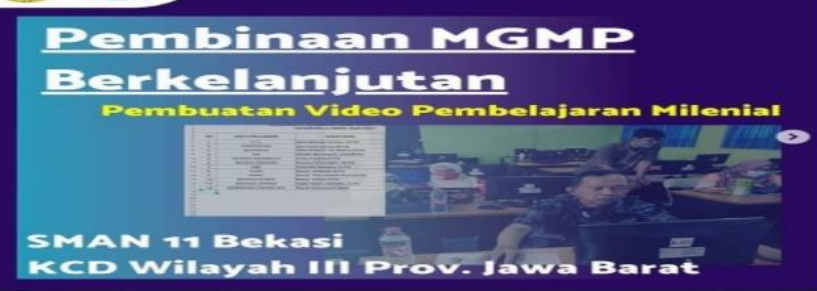

- Mindia \& 01 Maret 2021 Read: 65

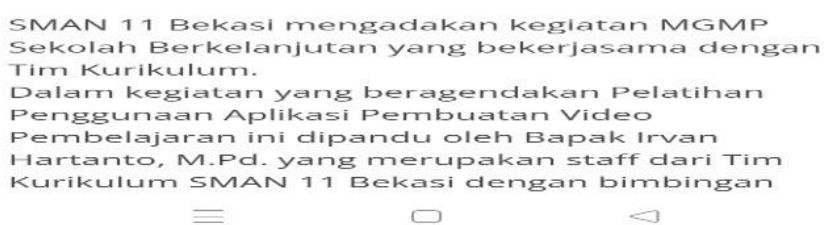

Gambar 4. Pembinaan MGMP Berkelanjutan

d. Optimalisasi MGMP Sekolah Berkelanjutan "Media Pembelajaran Berbasis Aplikasi Android dan Broadcast" yang dilaksanakan pada 20-22 Juni 2021.

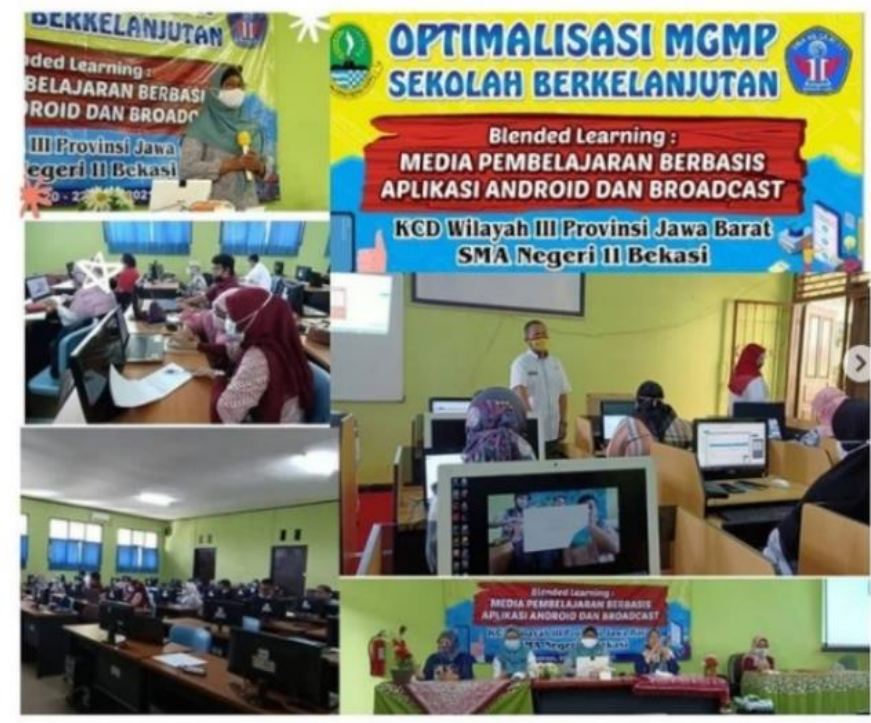

Gambar 5. Optimalisasi MGMP Sekolah Berkelanjutan "Media Pembelajaran Berbasis Aplikasi Android dan Broadcast"

e. Program Kegiatan MGMP Sekolah Berkelanjutan "Peningkatan Mutu Proses Pembelajaran" yang dilaksanakan pada tanggal 14 Oktober 2021 
116 The Implementation of Cipp Model in Evaluation MGMP Indonesian Language Program at Senior High School 11 , Bekasi

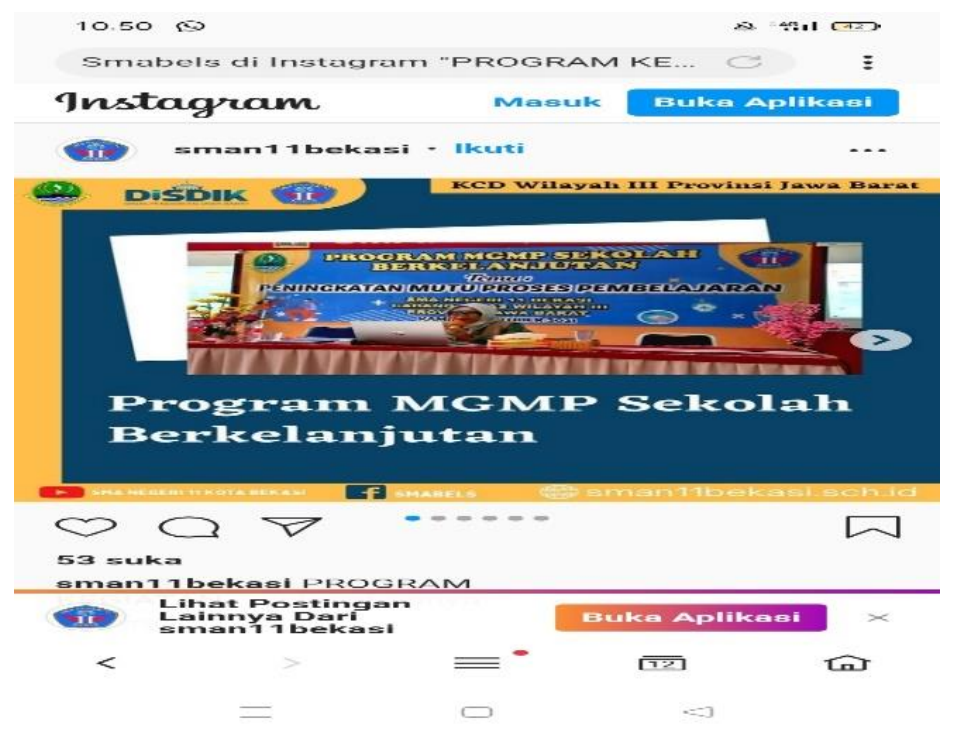

Gambar 6. Program Kegiatan MGMP Sekolah Berkelanjutan

Hasil evaluasi Product (Hasil) Program MGMP Bahasa Indonesia SMAN 11 BEKASI dinilai dari Pencapaian Program dalam Meningkatkan Profesionalisme Guru Bahasa Indonesia di SMAN 11 Bekasi.

a. Upaya meningkatkan kinerja guru Bahasa Indonesia. Hasil evaluasi pada unsur upaya meningkatkan kinerja guru Bahasa Indonesia diperoleh data dari hasil wawancara dalam bentuk upaya yang dilakukan oleh kepala sekolah dan keikutsertaan guru dalam MGMP. Kepala sekolah membuka akses dan mendorong para guru untuk mengikuti kegiatan MGMP. Guru-guru yang aktif dalam MGMP akan berdampak pada peningkatan kualitas pembelajaran di kelas. Peningkatan kinerja guru dalam kegiatan MGMP membantu secara administrasi, proses, dan penilaian.

b. Upaya meningkatkan kompetensi guru Bahasa Indonesia Kompetensi guru meliputi kompetensi pedagogik, kompetensi kepribadian, kompetensi sosial, dan kompetensi profesional yang diperoleh melalui pendidikan profesi. Upaya peningkatan kompetensi guru dalam kegiatan MGMP diisi dengan pemberian materi melalui kegiatan MGMP. Kemudian, materi-materi itu diberikan dalam bentuk dokumentasi. Selain itu, diberikan bimbingan dalam kegiatan MGMP.

c. Upaya meningkatkan profesionalisme guru Bahasa Indonesia Tugas keprofesionalan menyangkut perencanaan, pelaksanaan, dan penilaian pembelajaran merupakan menu dalam kegiatan MGMP Bahasa Indonesia. Kegiatan diisi dengan materi yang berkaitan dengan penguasaan bahan pelajaran yang hendak diajarkan, metode, dan model pembelajaran. Guru bahasa Indonesia yang mengikuti kegiatan MGMP dapat menghasilkan sebuah produk pembelajaran yang dikumpulkan menjadi satu dalam bentuk kanal YouTube "MGMP Bahasa Indonesia SMAN 11 BEKASI.

\section{Simpulan}

Secara aspek context evaluation (evaluasi konteks), Perencanaan Program MGMP Bahasa Indonesia di SMAN 11 BEKASI yang meliputi: visi, misi, tujuan, program kerja, struktur kepengurusan, keanggotaan, narasumber, sumber dana, dan sarana prasarana secara umum cukup baik karena hampir semu kegiatan MGMP dapat terlaksana. Keikutsertaan guru bahasa Indonesia dalam menjalankan Program MGMP Bahasa Indonesia di SMAN 11 BEKASI perlu dipertahankan atau ditingkatkan lagi. Pelaksanaan Program MGMP Bahasa Indonesia di SMAN 11 BEKASI pada pengelolaan program sudah memenuhi semua unsur, yaitu sudah memiliki pedoman kerja yang mengatur pengelolaan secara tertulis dan melakukan evaluasi terhadap kegiatan yang dilaksanakan sesuai kriteria yang ditetapkan pada aspek process evaluation (evaluasi proses). Pencapaian Program MGMP dalam meningkatkan profesionalisme guru Bahasa Indonesia di SMAN 11 BEKASI sangat baik sesuai dengan kriteria indikator keberhasilan yang ditetapkan dalam aspek product evaluation (evaluasi hasil). Pencapaian Program MGMP dalam meningkatkan profesionalisme guru Bahasa Indonesia diharapkan dapat terus berjalan dengan komitmen yang baik pula. Setelah dilakukan evaluasi program MGMP ini, peneliti merekomendasikan penelitian berikutnya untuk meneliti keefektivitasan program MGMP dalam proses pembelajaran di kelas. 


\section{Ucapan Terima Kasih}

Penulis ucapkan terima kasih dosen pengampu mata kuliah Tes Bahasa dan Evaluasi Program yang telah mendukung penelitian evaluasi program ini. Terima kasih pula penulis ucapkan kepada Wakasek Bidang Kurikulum SMAN 11 BEKASI Ibu Hj. Ririn Setyorini, M, Pd., Ketua MGMP SMAN 11 BEKASI Bapak Irvan Hartarto, M.Pd., dan Guru Bidang Studi Bahasa Indonesia Ibu Sisworohati, M.Pd. yang telah berkenan membantu peneliti dalam mengumpulkan data untuk mengevaluasi sebuah program bahasa sehingga penelitian ini dapat diselesaikan.

\section{Daftar Rujukan}

Asfaroh, Jati Aurum, et al. "Development of the Evaluation Instrument Use CIPP on the Implementation of Project Assessment Topic Optik." AIP Conference Proceedings, vol. 1868, no. August, 2017, doi:10.1063/1.4995190.

Bulhayat, Bulhayat. "Evaluasi Model CIPP Pada Implementasi KTSP Pendidikan Agama Islam Di Sekolah Menengah Atas Jombang." Al-Adabiya: Jurnal Kebudayaan Dan Keagamaan, vol. 14, no. 01, 2019, pp. 85-102, doi:10.37680/adabiya.v14i01.105.

Fahruddin. "Evaluasi Program Pembelajaran Sejarah Menggunakan Model Context, Input, Process, Product (CIPP)." ... : Jurnal Program Studi Pendidikan Sejarah, vol. 8, no. 2, 2020, pp. 199-211.

Junanto, Subar, and Nur Arini Asmaul Kusna. "Evaluasi Program Pembelajaran Di PAUD Inklusi Dengan Model Context, Input, Process, and Product (CIPP)." Inklusi, vol. 5, no. 2, 2018, p. 179, doi:10.14421/ijds.050202.

Juwairiyah. Profesionalisme Guru Dalam Melaksanakan KKG Dan MGMP. Balai Diklat Keagamaan Medan, 2014.

Mahmudi, Ihwan. "CIPP: Suatu Model Evaluasi Program.” Jurnal University of Darussalam, vol. 6, no. 1, 2011, pp. 111-25.

Mawarsari, Venissa Dian, et al. "Desain Evaluasi Pembelajaran Matematika Menggunakan.” Jkpm, vol. 1, no. September, 2014, pp. 42-48.

Mesiono. "Dalam Tinjauan Evaluasi Program." Ilmu Pendidikan Dan Kependidikan, vol. 4, no. 2, 2017, pp. 1-22, http://repository.uinsu.ac.id/3485/1/EVALUASI PROGRAM.pdf.

Mufid, Muhammad. "Evaluasi Model Context, Input, Process and Product (CIPP) Program Baca Tulis AlQur'an Di Institut Agama Islam Negeri Pekalongan." Quality, vol. 8, no. 1, 2020, p. 1, doi:10.21043/quality.v8i1.6908.

Munthe, Ashiong P. "PENTINGYA EVALUASI PROGRAM DI INSTITUSI PENDIDIKAN: Sebuah Pengantar, Pengertian, Tujuan Dan Manfaat." Scholaria: Jurnal Pendidikan Dan Kebudayaan, vol. 5, no. 2, 2015, p. 1, doi:10.24246/j.scholaria.2015.v5.i2.p1-14.

Oktaviyani, A., Herpratiwi, dan Sukirlan, M. "Evaluasi Program Pembelajaran Bahasa Inggris." Jurnal Teknologi Informasi Komunikasi Pendidikan, vol. 3, no. 4, 2015, pp. 1-11.

Ortiz, Diana Isabel Quinchía, et al. "Evaluación Del Contexto de Un Programa de Competencia Lectora En Inglés En Una Universidad Pública En Colombia a Través Del Modelo de Evaluación CIPP.” Ikala, vol. 20, no. 3, 2015, pp. 293-314, doi:10.17533/udea.ikala.v20n3a02.

Sukardi. Evaluasi Pendidikan: Prinsip \& Operasionalnya. Bumi Aksara, 2012.

Yanti, Nafri, et al. "Pelatihan Penulisan Karya Ilmiah Pada Musyawarah Guru Mata Pelajaran (Mgmp) Bahasa Indonesia Di Sma/Smk Kota Bengkulu." Dharma Raflesia : Jurnal Ilmiah Pengembangan Dan Penerapan IPTEKS, vol. 16, no. 1, 2018, pp. 81-88, doi:10.33369/dr.v16i1.4829.

Zhang G, Zeller N, Griffith R, Metcalf D, Williams J, Shea C, and Misulis K. "Using the Context, Input, Process, and Product Evaluation Model (CIPP) as a Comprehensive Framework to Guide the Planning, Implementation, and Assessment of Service-Learning Programs." Journal of Higher Education Outreach and Engagement, vol. 15, 2011, p. 57. 